Available online on 15.01.2020 at http://jddtonline.info
Open Access to Pharmaceutical and Medical Research
unrestricted non-commercial use, provided the original work is properly cited

Open? Access

Research Article

\title{
Qualitative Phytochemical Screening, GCMS Studies and In-Vitro Anti- Oxidative Properties of Aqeuous Leaf Extract of Gnetum africanum
}

\author{
Ezekwe A.S. ${ }^{1}$, Ugwuezumba P.C. ${ }^{2}$, Nwankpa P. ${ }^{*}$, Egwurugwu J.N. ${ }^{2}$, Ekweogu C.N. ${ }^{1}$, Emengaha F.C. ${ }^{1}$, Akukwu D. ${ }^{3}$ \\ 1 Department of Medical Biochemistry, Imo State University Owerri, Nigeria \\ 2 Department of Medical Physiology, Imo State University Owerri, Nigeria \\ ${ }^{3}$ Department of Human Anatomy and Neurobiology, Imo State University Owerri, Nigeria
}

\begin{abstract}
This study aimed at carrying out a qualitative phytochemical screening, GC-MS studies and in-vitro antioxidant properties of aqueous leaf extract of Gnetum africanum. The qualitative phytochemical screening of the aqueous leaf extract of Gnetum africanum was done using standard procedures and revealed the presence of terpenoids, saponins, tannins, steroids, flavonoids, alkaloids, cardiac glucosides and phenols. The GCMS screening revealed the presence of 14 compounds, 6 out of the 14 compounds were most prominent. The compound with the highest percentage peak area was caffeine with peak area of $96.9 \%$, followed by n-Hexadacanotic acid with peak area of $60.9 \%$, 2 -methoxy-4vinylphenol with peak area of 55.9\%, tetradacanoic acid with peak area of $50.3 \%$, cyclopentaneundecanoic acid with peak area of $47.8 \%$ and 2 cyclo-penten-1-2-hydroxy with peak area of $43.6 \%$ respectively. In-vitro determination of antioxidant property of leaf extract of Gnetum africanum was done photometrically using 2,2-dyhenyl-l-picrylhydrazyl (DPPH) assay. The DPPH scavenging ability of the leaf extract (43.2, $60.5,68.8$, and 75.7$)$ was statistically significant at $\mathrm{p}<0.05$ when compared with the standard drug ascorbic acid (81.1, 82.6, 85.1, and 90.4) $\%$ at $10,20,30$ and $40 \mathrm{mg} / \mathrm{l}$. In conclusion, the leaf extract of Gnetum africanum is loaded with a host of important phytochemicals and has antioxidant properties which increase in potency with increase dose.
\end{abstract}

Keywords: Phytochemical Screening, GCMS Studies, Anti-Oxidant, Gnetum africanum

Article Info: Received 10 Nov 2019; Review Completed 12 Dec 2019; $\quad$ Accepted 19 Dec 2019; Available online 15 Jan 2020

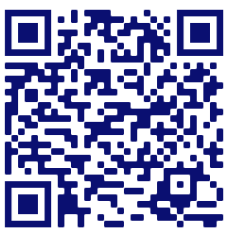

Cite this article as:

Ezekwe AS, Ugwuezumba PC, Nwankpa P, Egwurugwu JN, Ekweogu CN, Emengaha FC, Akukwu D, Qualitative Phytochemical Screening, GCMS Studies and In-Vitro Anti-Oxidative Properties of Aqeuous Leaf Extract of Gnetum africanum, Journal of Drug Delivery and Therapeutics. 2020; 10(1):11-17 http://dx.doi.org/10.22270/jddt.v10i1.3813

Nwankpa P., Department of Medical Biochemistry, Imo State University Owerri, Nigeria

\section{INTRODUCTION}

Acceptance and use of plant products for health care delivery have continued to gain popularity over the years. Plants are the richest sources of bioactive compounds and have been the basis of many traditional medicines throughout the world for thousands of years[1]. Natural products, either as pure compounds or as standardized extracts, provide unlimited opportunities for new drug discoveries because of the unmatched availability of chemical diversity[2].. Clardy and Walsh [3] reported that small molecules from medicinal plants called natural products are still major sources of innovative therapeutic agents for various conditions, including infectious diseases. The medicinal value of the plants useful for healing and cure of human diseases is attributed to presence of phytochemical constituents ${ }^{[4]}$. Among these phytochemicals are flavonoids, alkaloids, phenols, saponins etc [5,6]. According to Ogbu et al [7]., tropical African sub-regions are home to many useful medicinal plants, however, there are many of them whose potentials are yet to be harnessed or domesticated in tropical African Sub-regions.

Gnetum africanum (G. africanum) belongs to the Family Gnetaceae of the Order Gnetales[8]. It grows as a wild evergreen climbing plant in the rain forest of Nigeria where it is searched for and highly priced in the regional markets. The seed of G. africanum is oval in shape, small in size with diameter of $0.5 \mathrm{~cm}$, green in colour when unripe but turns red with ripening and enclosed in a fleshy envelope[9]. The leaves are decussately opposite, sometimes in a whorl of 3 , petiole up to $1 \mathrm{~cm}$ long with $3-6$ pairs of strongly curved lateral veins looped near the margin. Gnetum africanum is one of the most popular green leafy vegetables in Nigeria, and it is gaining equal popularity as a delicious vegetable in other African countries such as Cameroun, Gabon, Congo and Angola [10]. It is known as "eru, okok, mfumbua or fumbua"in Cameroun, "koko" in Angola and Central African Republic [11] 
and "Ntoumou" in Gabon. In Nigeria, it is called "afang" in Ibibio and Efik; "okazi" in Igbo; "yala" in Ogoja and "ajaabaje or ajakotale" in Yoruba[11]..

Phytochemical screening of Gnetum africanum leaves revealed the presence of alkaloids, saponin, glucosides and tannins $[9,12,13]$. G.africanum leaves have medicinal and great culinary values especially in West Africa. It was reported to show anti-inflammatory, anti-carcinogenic and antioxidant activities [14]. G. africanum is employed in Nigerian folk medicine for the treatment of enlarged spleen[15], piles, high blood pressure[16]., sore throats and as a cathartic[11]. In DR Congo it is used to stop nausea and as antidote to some forms of poison and snake bites[11, 17]. In Cameroun the leaves are taken as an enema against constipation and to ease child birth, chewed to mitigate the effects of drunkenness [11]. and used for treating diabetes, boils and fungal infection in the fingers [17].The seeds are used as fungicide for dressing fresh and septic wounds and can also be chewed raw for the management of excessive urination [16].. G. africanum leaves are eaten raw as local salad, shredded and used in preparing soups and stews[11]. They are also put to minor use by the Ibos and the Efiks/Ibibios where they are eaten as a salad mixed with dry fish or meat, certain spices and palm oil[18].

Antioxidants are the body's defensive mechanisms that protect the tissues from free radical toxicity through their scavenging ability. Free radicals are highly reactive molecules which arise from the body's biochemical reactions [19] and become toxic when produced in excess quantity[20]. Free radicals are associated with oxidative stress and implicated in the pathogenesis of various chronic and degenerative disorders such as cancer, aging, Alzheimer's disease, diabetes, autoimmune disorders and cardiovascular diseases [21, 22].. A variety of free radical scavenging antioxidants are found in fruits, leaves and other parts of plants and these antioxidants help in converting the free ROS to less reactive species[23].. With increasing oxidative stress related health challenges, it has become very pertinent to explore and use more plant-based products as food. Eating more plant-based foods which are rich in phytochemicals according to Heather and Talcott [24]. prevent oxidative stress in the body and according to reports by [25,26,27], regular intake of plants fruits and vegetables with antioxidative potentials help in the fight against chronic diseases and in enhancing human longevity and well-being.. Studies on the phytochemistry of Gnetum africanum have been reported but there is dearth of information regarding its GCMS-based analysis and its antioxidative potentials. This study therefore aimed at investigating qualitatively the phytochemicals, GCMS-based compositions and in-vitro antioxidant properties of aqueous extract of Gnetum africanum.

\section{MATERIALS AND METHODS}

\section{Identification and Collection of Plant materials}

Fresh leaves of Gnetum africanum plant were harvested from a local garden in Ulakwo, Owerri-North L.G.A of Imo State Nigeria. The plant was identified and authenticated at the department of Plant Science and Biotechnology, Imo State University, Owerri. The leaves were removed from the stalk, thoroughly washed under running tap water to remove unwanted debris and air-dried at room temperature for 14 days. The dried leaves were then pulverized to fine powder with the aid of a mechanical grinder and kept in labeled airtight containers under dry conditions until required for use.

\section{Aqueous leaf extraction of Gnetumafricanum}

One hundred and twenty grams (120g) of ground leaf of Gnetum africanum was macerated in 1litre of distilled water for 24hrs. This was thereafter filtered with sterile filter paper (Whatman No. 1) and evaporated to dryness at $40^{\circ} \mathrm{C}$ in a vaccum using a rotary evaporator RE52. Approximate concentrations of the extract were constituted to the required doses for the treatment of the animals using normal saline.

Qualitative phytochemical screening of the aqueous extract of $G$. africanum

Qualitative phytochemical screening of the extract was done to detect the presence or absence of secondary metabolites (phytochemicals) using standard procedures as described below.

\section{Test for terpenoids[28].}

\section{Salkowski Test}

$5 \mathrm{ml}$ of the extract was mixed in $2 \mathrm{ml}$ of chlorofoam, and $3 \mathrm{ml}$ of concentrated $\mathrm{H}_{2} \mathrm{SO}_{4}$ was carefully added to form a layer. A reddish brown colouration of the interface was formed indicating a positive result for the presence of terpenoid compounds.

\section{Test for saponins[28]}

\section{Emulsion test}

$4 \mathrm{ml}$ of distilled water was added to $2 \mathrm{ml}$ of the extract and shaken vigorously for 2 min after which a few drops of olive oil were added. Formation of an emulsion showed the presence of saponins.

\section{Test for tannins ${ }^{[28]}$.}

\section{Ferric chloride test}

To $1.0 \mathrm{ml}$ portion of the extract, $4.0 \mathrm{ml}$ of distilled water was added and a few drops of $10 \%$ ferric chloride solution were also added. The solution was then observed for blue or green precipitate colouration indicating the presence of tannins.

\section{Test for steroid [28]}

$5 \mathrm{ml}$ of aqueous extract was added to $2 \mathrm{ml}$ chloroform and 3 $\mathrm{ml}$ of concentrated $\mathrm{H}_{2} \mathrm{SO}_{4}$ was added cautiously for a reddish brown intermittent layer, which confirms a positive result.

\section{Test for flavonoids ${ }^{[28]}$}

\section{Lead acetate test}

To $2.0 \mathrm{ml}$ portion of the extract, few drops of $10 \%$ lead acetate solution were added. A cream or light yellow colouration showed the presence of flavonoids.

\section{Aluminium chloride test}

To $2.0 \mathrm{ml}$ portion of the extract, few drops of $1 \%$ aluminum chloride solution was added and observed for light yellow colouration. A yellow precipitate indicated the presence of flavonoids.

\section{Test for alkaloid[28]}

A few drops of the following reagents were added to each of $2.0 \mathrm{ml}$ of the extract, and observed for colour change:

\section{Dragendorf reagent}

A red to orange precipitate indicated the presence of alkaloids. 


\section{Wagner's reagent}

A reddish or deep-brown precipitate indicated the presence of alkaloids

\section{Test for cardiac glycosides[28]}

A known mass of $1 \mathrm{~g}$ of sample and $10 \mathrm{ml}$ of water were boiled for 5 minutes. Then $400 \mu \mathrm{l}$ of equal $(\mathrm{v} / \mathrm{v})$ mixture of Fehling's solutions (A and B) was added to $2 \mathrm{ml}$ of filtrate to which $2 \mathrm{ml}$ of dilute ammonia solution ( $\mathrm{NH}_{3}(\mathrm{aq})$ ) was added and boiled for 5 - 10 mins. The filtrate changed to a brick red precipitate, indicating the presence of cardiac glycosides.

\section{Test for phenol}

\section{Ferric chloride test}

To $2 \mathrm{ml}$ of ethanol, $0.05 \mathrm{~g}$ of the extract was added followed by few drops of aqueous solution of ferric chloride. A formation of reddish colour precipitate indicates the presence of phenols.

Gas Chromatography-Mass Spectrometry (GC-MS) analysis of the aqueous extract of Gnetum africanum

The aqueous leaf extract of Gnetum africanum was subjected to GC-MS analysis on the instrument GCMS-QP2010 PLUS SHIMADZU, JAPAN. The oven temperature was programmed at $60^{\circ} \mathrm{C}$ for $0 \mathrm{~min}$, was gradually increased to $140^{\circ} \mathrm{C}$ at 4.0 min and then ending with $250^{\circ} \mathrm{C}$ at $6 \mathrm{~min}$. A sample volume of $8.0 \mu \mathrm{l}$ was injected for analysis. Helium gas $99.995 \%$ of purity was used as a carrier gas as well as an eluent. The flow rate of helium gas was set to $1.61 \mathrm{ml} / \mathrm{min}$. The sample injector temperature was maintained at $200{ }^{\circ} \mathrm{C}$ and the split ratio was 1.0 throughout the experiment periods.

The ionization mass spectroscopic analysis was done with $70 \mathrm{eV}$. The mass spectra were recorded for the mass range $35-800 \mathrm{~m} / \mathrm{z}$ for about $25 \mathrm{~min}$. Identification of components was based on comparison of their mass spectra. As the compounds separated on elution through the column, they were detected in electronic signals. As individual compounds eluted from the Gas chromatographic column, they entered the electron ionization detector where they were bombarded with a stream of electrons causing them to break apart into fragments. The fragments were actually charged ions with a certain mass.
The $\mathrm{m} / \mathrm{z}$ ratio obtained was calibrated from the mass spectrum graph obtained which was the fingerprint of the molecule. Interpretation of GC-MS was conducted using the database of National Institute of Standard and technology (NIST) having more than 62,000 patterns. The spectrum of the unknown component was compared with the spectrum of the known components stored in the NIST Library 2008 WILEY8, FAME. The Name, Molecular weight and structure of the components of the test materials were ascertained.

Determination (In-vitro) of the antioxidant property of the extract using 2,2-dyphenyl-1-picrylhydrazyl (DPPH) photometric Assay

The procedure described by [29] was used in determining the free radical scavenging activity of the Gnetum africanum extract. The extract was analyzed by the DPPH assay using a spectrophotometer. $1 \mathrm{~mL}$ of $0.5 \mathrm{mM}$ DPPH (in methanol) in a cuvette was mixed with aqueous extract at concentrations $(25,50,100,200$ and 400) $\mu \mathrm{g} / \mathrm{ml}$. After 30 minutes of incubation in a dark room, the absorbance was taken at $517 \mathrm{~nm}$. The experiment was done in triplicate and the percentage antioxidant activities were calculated as follows.

$\%$ antioxidant activity $(\mathrm{AA})=100-[\{$ (sample abs-blank abs $)$ $\mathrm{x} 100\} /$ abs of control] Where abs = absorbance

One millilitre of methanol plus $2.0 \mathrm{~mL}$ of the test extract was used as the blank while $1.0 \mathrm{~mL}$ of the $0.5 \mathrm{nM}$ DPPH solution plus $2.0 \mathrm{~mL}$ of methanol was used as the negative control. Ascorbic acid (Vitamin C) was used as reference standard.

\section{Statistical Analysis}

The data generated in this study was entered, cleaned and coded in excel sheets and was statistically analyzed using the SPSS/IBM version 21 software. Means and standard errors of mean were calculated. Statistical differences between the experimental and control groups were determined using ANOVA and values were considered significant at $\mathrm{p}<0.05$. Descriptive statistics (percentages and signs) were also used.

\section{RESULTS}

The results are presented in tables and figures (graphs). The qualitative phytochemical screening and GC-MS studies are presented in tables while the antioxidant properties are presented in figures.

Table 1: Qualitative phytochemical screening of aqueous leaf extract of Gnetumafricanum

\begin{tabular}{|l|l|l|l|}
\hline Phytochemical & Method of Test & $\begin{array}{l}\text { Presence/ } \\
\text { Absence }\end{array}$ & Indicator \\
\hline Terpenoids & Salkowski test & + & Reddish brown colour \\
\hline Saponins & Emulsion test & + & Emulsion formation \\
\hline Tannins & Ferric chloride test & + & Blue or Green ppt colour \\
\hline Steroids & Trease and Evans, 1996 & + & Reddish brown intermittent layer \\
\hline Flavonoids & Lead Acetate and Aluminium chloride test & + & Yellow colour \\
\hline Alkaloids & Dragendorf Reagent and Wagner's Reagent & + & Red to Orange ppt and deep brown ppt \\
\hline Cardiac glucosides & Fehling's solution (A and B) & - & Brick red ppt \\
\hline Phenols & Ferric chloride test & + & Reddish colour \\
\hline
\end{tabular}

Table 1 shows qualitative phytochemical screening of aqueous extract of Gnetum africanum. Presence of phytochemical is shown with a + sign while absence is shown with a - sign. All the phytochemicals investigated are present in the leaf extract of Gnetum africanum except cardiac glucoside which was found to be absent. 
Table 2: Composition of aqueous leaf extract of $G$. africanum based on GC-MS analysis

\begin{tabular}{|l|l|l|l|l|}
\hline S.N. & Name of Compound & Molecular Formula & Molecular Weight (MW) & Peak Area \\
\hline 1 & 2-cyclopenten-1-2-hydroxy & $\mathrm{C}_{5} \mathrm{H}_{6} \mathrm{O}_{2}$ & 98 & $43.6 \%$ \\
\hline 2 & Estragole & $\mathrm{C}_{10} \mathrm{H}_{12} \mathrm{O}$ & 148 & $32.8 \%$ \\
\hline 3 & 2-methoxy-4-vinylphenol & $\mathrm{C}_{9} \mathrm{H}_{10} \mathrm{O}_{2}$ & 150 & $55.9 \%$ \\
\hline 4 & 5-chloropentanoic acid 4-methylpentyl ester & $\mathrm{C}_{11} \mathrm{H}_{21} \mathrm{ClO}_{2}$ & 220 & $9.39 \%$ \\
\hline 5 & 1,3 Benzodioxole, 4-methoxy-6-(2-propenyl) & $\mathrm{C}_{11} \mathrm{H}_{12} \mathrm{O}_{3}$ & 192 & $17.3 \%$ \\
\hline 6 & Tetradacanoic acid & $\mathrm{C}_{14} \mathrm{H}_{28} \mathrm{O}_{2}$ & 228 & $50.3 \%$ \\
\hline 7 & Hexyl amine & $\mathrm{C}_{13} \mathrm{H}_{25} \mathrm{~N}$ & 195 & $17.0 \%$ \\
\hline 8 & Caffiene & $\mathrm{C}_{8} \mathrm{H}_{10} \mathrm{~N}_{4} \mathrm{O}_{2}$ & 194 & $96.9 \%$ \\
\hline 9 & 3-P-methyl-d-glucose & $\mathrm{C}_{7} \mathrm{H}_{14} \mathrm{O}_{6}$ & 194 & $12.2 \%$ \\
\hline 10 & n-Hexadacanotic acid & $\mathrm{C}_{16} \mathrm{H}_{32} \mathrm{O}$ & 256 & $60.9 \%$ \\
\hline 11 & Phytol & $\mathrm{C}_{20} \mathrm{H}_{40} \mathrm{O}$ & 296 & $39.0 \%$ \\
\hline 12 & Linoelaidic acid & $\mathrm{C}_{18} \mathrm{H}_{32} \mathrm{O}_{2}$ & 280 & $20.2 \%$ \\
\hline 13 & Cyclopentaneundecanoic acid & $\mathrm{C}_{16} \mathrm{H}_{3} \mathrm{O}_{2}$ & 254 & $47.8 \%$ \\
\hline 14 & Cis, cis, cis-7-10-13-Hexadecatrienal & $\mathrm{C}_{16} \mathrm{H}_{26} \mathrm{O}$ & 234 & $8.6 \%$ \\
\hline
\end{tabular}

Table 2 shows 14 compounds obtained from the aqueous leaf extract of Gnetum africanum, their MW and their percentage (\%) peak areas using GCMS method. Out of these 14 compounds, six (6) were most prominent as indicated by their percentage (\%) peak areas. The prominent compounds include caffeine (96.9\%), n-Hexadacanotic acid (60.9\%), 2-methoxy-4-vinylphenol (55.9\%), Tetradacanoic acid (50.3\%), Cyclopentaneundecanoic acid (47.8\%), 2-cyclopenten-1-2-hydroxy (43.6\%). Three (3) were less prominent while the remaining five (5) were only present in minute amounts.

\section{GAS-Chromatography Mass Spectrometry Graph}

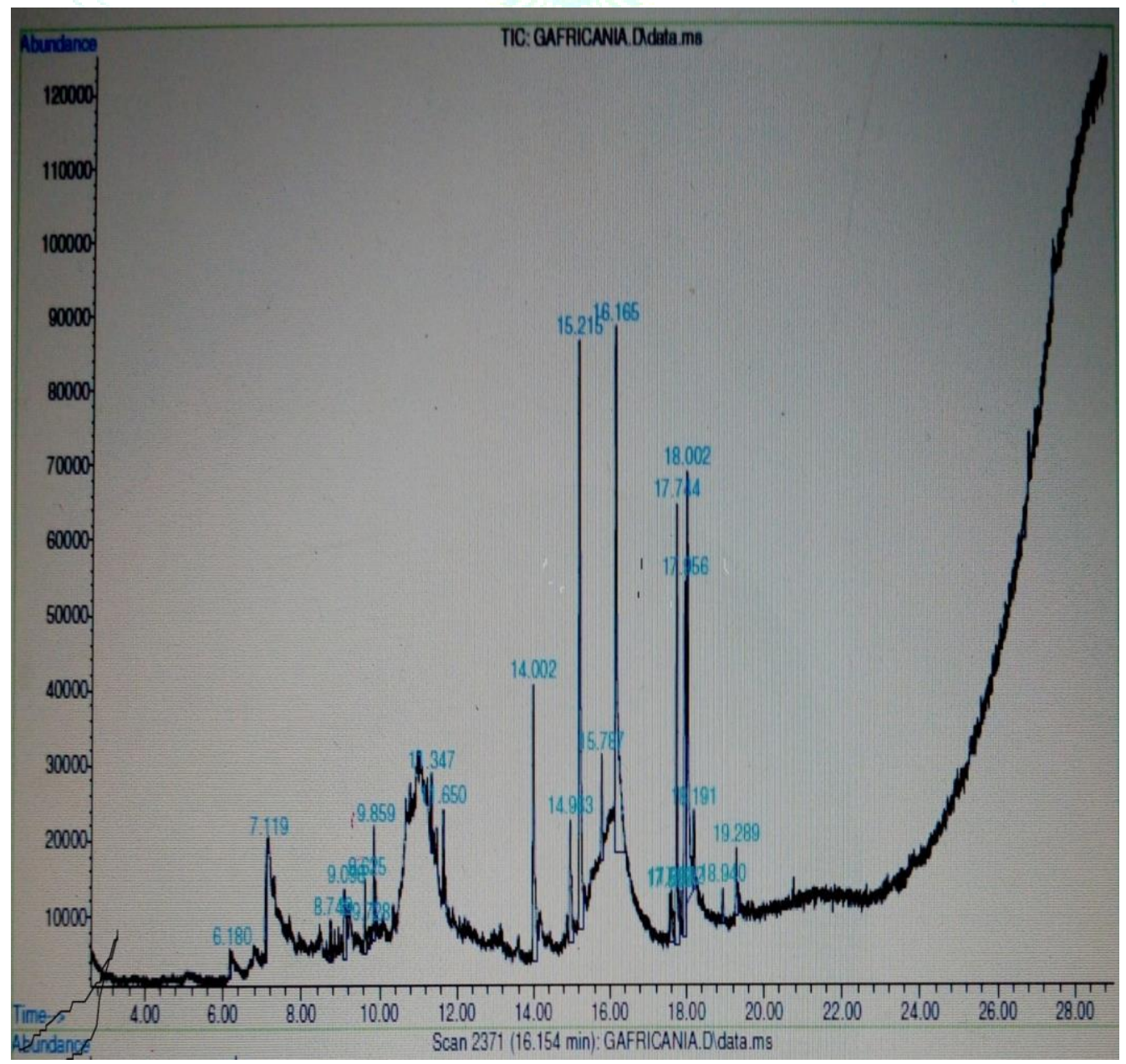

Figure 1: GAS-Chromatography Mass Spectrometry Graph 


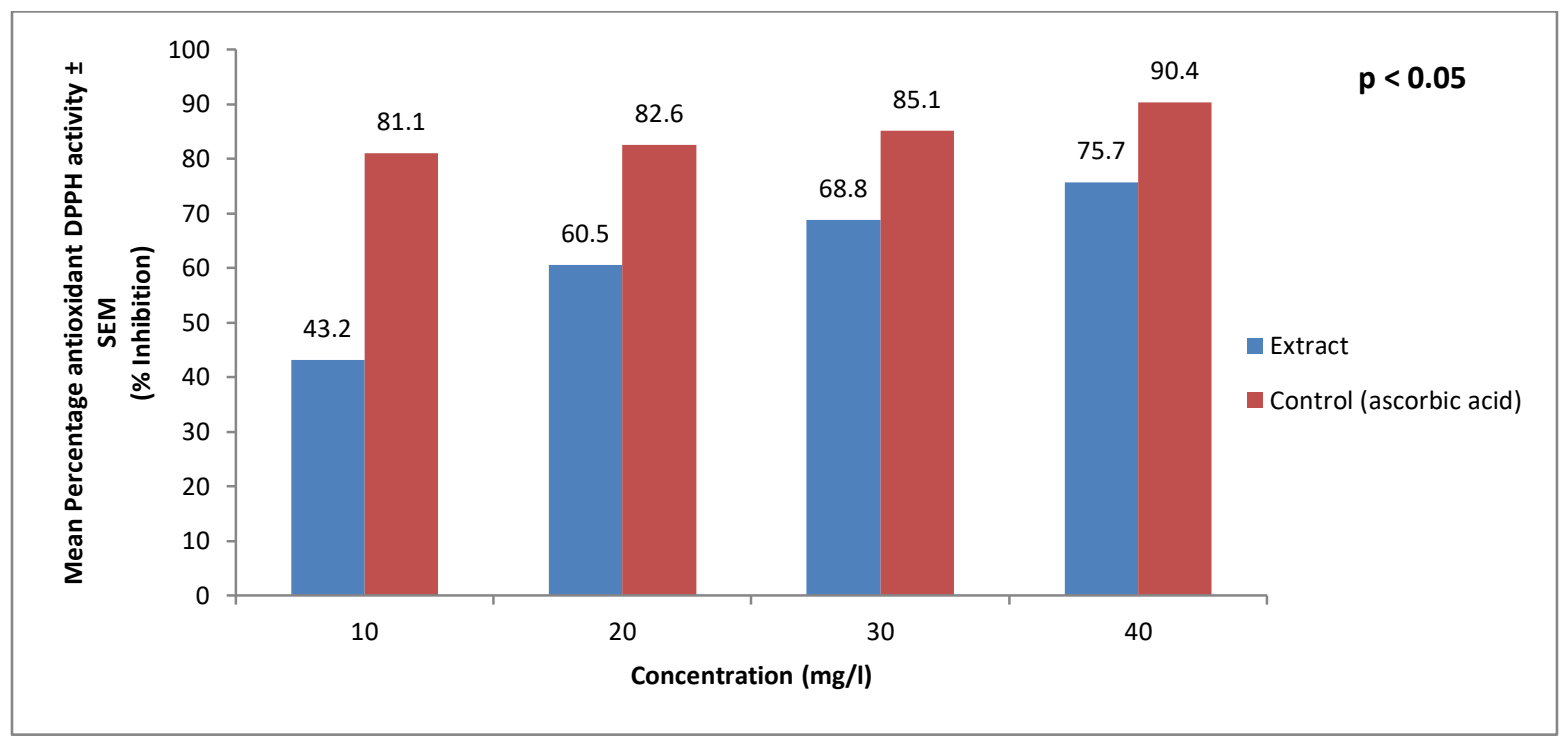

Figure 2: 2,2-Diphenyl-1-picryhydrazyl (DPPH) radical scavenging photometric assay.

Figure 2 shows the graphical representation of the mean DPPH radical scavenging activity obtained by photometric assay. The horizontal axis represents the concentration of leaf extract of Gnetum africanum and a standard drug ascorbic acid measured in $\mathrm{mg} / \mathrm{l}$ while the vertical axis represent the mean percentage antioxidant activity of both the standard ascorbic acid and seed extract.

The legend shows leaf extract in blue colour and ascorbic acid in red colour. From the graph it can be deduced that the extract possesses good DPPH radical scavenging activity $(43.2,60.5,68.8$, and 75.7$) \%$ which is statistically significant at $\mathrm{p}<0.05$ when compared with the standard ascorbic acid (81.1, 82.6, 85.1, and 90.4) \% at 10, 20, 30 and $40 \mathrm{mg} / \mathrm{l}$. It can also be deduced from the graph that the DPPH radical scavenging activity of the leaf extract of Gnetum africanum is dose dependent.

\section{DISCUSSION AND CONCLUSION}

Phytochemicals are natural bioactive compounds found in plants that work with nutrients and dietary fiber for disease protection [30]. The medicinal value of the plants useful for healing and cure of human diseases is attributed to presence of phytochemical constituents[4] . The leaves of plants according to Owolabi et al [31] and Egba et al. [32] provide both nutritional and medicinal benefits principally due to their nutrient composition and secondary bioactive metabolites which are known to possess antioxidant, antibacterial, anti-inflammatory, anti-sickling, hypoglycaemic and immunomodulatory properties.

Qualitative Phytochemical screening of aqueous extract of Gnetum africanum in the present study revealed the presence of terpenoids, saponins, tannins, steroids, flavonoids, alkaloids and phenols. The phytochemical constituents of $G$. africanum obtained in this study are not in total agreement with the reports of Dike[12] and Okerulu and Onyema[9]. Dike [12] reported the presence of alkaloids, saponins, flavonoids and tannins while Okerulu and Onyema[9] reported the presence of alkaloids, Glycosides, saponins and tannins. The little discrepancies in these findings may be due to differences in the methods of extraction and differences in species. The present study was done on domestic species while that of Dike; Okerulu and Onyema were each done on wild species of G. africanum.
G. africanum leaves can therefore be said to be good reservoirs of a host of important phytochemicals that promote wellbeing and also capable of combatting certain disease conditions.Terpenoidshave both antimalarial and hypoglycaemic effects[33, 34] while Saponins have been shown to have hypotensive, hypocholesterolaemic, and cough depressant activities [35] According to[34] , saponins are active agents against fungal infections. Tannins possess antiviral, antibacteria and also potent against degenerative diseases. Report also has it that tannins play major role as anti-diarohoea and anti-haemoharragic agents[36] . Steriods promote nitrogen retention in osteoporosis, have therapeutic application as cardiac drugs and play important roles in the functions of sex hormones [37]. Flavonoids are known for their antioxidant activities and can help protect the body against Reactive Oxygen Species (ROS) which are involved in either the initiation or progression of carcinogenesis and other degenerative diseases. Reactive oxygen species cause oxidative damage by peroxidation and oxidation of cellular lipids, proteins and deoxyribonucleic acids[38] . Flavonoids act as hydrogen peroxide scavengers as they are oxidized by peroxidase [39]. Alkaloids have anticancer activity, CNS stimulatory effects and are used as anasthetics in ophthalmology[40]. Phenols act as natural antioxidants and are used as nutraceuticals for their anticancer and cardioprotective potentials ${ }^{[40]}$.

GC-MS analysis of the aqueous extract of $G$. africanum in this present study identified fourteen (14) compounds with six (6) of them being most prominent and including caffeine (96.9\%), n-Hexadacanotic acid (60.9\%), 2-methoxy-4vinylphenol (55.9\%), Tetradacanoic acid (50.3\%), Cyclopentaneundecanoic acid (47.8\%), 2-cyclopenten-1-2hydroxy $(43.6 \%)$. These compounds possess antioxidant, hypocholestrolemic, nematicide, pesticide, hemolytic, antiinflammatory properties and lubricant activities. Phytol with percentage peak area of $30 \%$ is a product of chlorophyll metabolism in plant and has the ability to reduce the risk of cardiovascular disease, stroke and heart attack. 0

Antioxidants are powerful substances that prevent oxidation and delay or inhibit the damaging effects of reactive oxygen species (ROS) to a target molecule. They have the ability to trap or scavenge free radicals thus protecting the body from free radical induced oxidative stress ${ }^{[41]}$. Oxidative stress affects all cell macromolecules including DNA, proteins and lipids causing mutation, protein inactivation and lipid 
peroxidation respectively[42] .This study showed a high free radical scavenging activity of the extract on DPPH at almost all concentrations but most especially at concentrations $20 \mathrm{mg} / \mathrm{l}, 30 \mathrm{mg} / \mathrm{l}$ and $40 \mathrm{mg} / \mathrm{l}$ when compared with that of ascorbic acid. This result is in tandem with the findings of [18] ) where high DPPH free radical scavenging ability of raw and cooked forms of Gnetum africanum was demonstrated. The high DPPH free radical scavenging ability of Gnetum qafricanum leaf extract must be attributed to its constituent phytochemicals alkaloids, flavonoids and tannins (polyphenols).There exist a strong positive relationship between total phenolic contents and antioxidant activity which appears to be the trend in many plant spece [43] . RiceEvans et al., [40] reported that under experimental conditions, the antioxidative potentials of plant phenolics are always linked to their electron donation, reducing power, and metal-chelating ability. Polyphenols have the ability to donate hydrogen atoms or electrons and to capture free radicals ${ }^{[44]}$ and this explains the antioxdative property of the extract.

The percentage inhibition of the free radical was dose dependent and the higher the concentration of the extract, the higher the percentage inhibition. Vitamin $\mathrm{C}$ which is a potent and safe antioxidant in medicine has a higher antioxidative ability than the extract.This may be due to the fact that vitamin $C$ is a refined drug.

In conclusion, the leaf extract of Gnetum africanum is loaded with a host of important phytochemicals and has antioxidant properties which increase in potency with increase dose. We therefore recommend regular consumption of Gnetum africanum as this will promote wellbeing and if properly harnessed, may be applied in the management and treatment of various chronic and degenerative disorders which oftentimes are oxidative stress related.

\section{REFERENCES}

1. Ingale, A. G. and Hivrale, A. U. Pharmacological studies of Passiflora sp. and their bioactive compounds. African Journal of Plant Science, 2010; 4(10): 417 - 426.

2. Cos, P., Arnold, J. V., Dirk, V. B. and Louis, M. (2006). Antiinfective potential of natural products: How to develop a stronger in vitro "proof-of-concept". Journal of Enthnopharmacology, 106: 290-302.

3. Clardy, J. and Walsh, C. Lessons from natural molecules. Nature, 2004; 432: 829 - 837.

4. Nostro A, Germano MP, Dangelo V, Marino A, Cannatelli MA. Extraction methods and bioautography for evaluation of medicinal plant antimicrobial activity. Lett. Appl. Microbiol. 2000; 30:379- 384.

5. Edeoga, H.O., Okwu, D.E., Mbaebie, B.O. Phytochemical constituents of some Nigeria medicinal plants. Afr. J. Biotech, 2005; 4(7):685-688.

6. Ene-obong, H.N., Okudu, H.O., Asumugha, V.U. Nutrient and photochemical composition of two varieties of Monkey kola (Cola parchyarpa and Cola lepidota) an underutilized fruit. Food Chem, 2016; 193:154-9.

7. Ogbu JU, Umeokechukwu CE. Aspects of fruit biology of three wild edible monkey Kola species fruits (Cola spp: Malvaceae). Annual Research \& Review in Biology; 2014; 4(12):20072014.

8. Dutta AC. Botany for degree students. 5th ed. Oxford: Oxford University Press; 2000, p. 37-42.

9. Okerulu IO, Onyema CT. Comparative Assessment of Phytochemicals, Proximate and Elemental Composition of Gnetumafricanum (Okazi) Leaves. American Journal of Analytical Chemistry; 2015; 6:604-609.

10. Eyo E, Abel U. Chemical composition and amino acid content of Gnetumafricanum leaves. Nig J NutrSci 1983; 4:52-57.

11. Burkill HM. Useful Plants of Tropical Africa. Vol. 2 families E-I. Royal Botanical Gardens, Kew. 1994; Pp 648.

12. Dike, M.C. Proximate and Nutrient Compositions of Some Fruits, Seeds and Leaves of Some Plant Species at Umudike,
Nigeria. ARPN-Journal of Agricultural and Biological Science, 2010; 5:7-16

13. Ekop, A.S. and Eddy, N.O. Comparative Studies of the Level of Toxicants in the Seed of Indian Almond (Ter- minaliacatappa) and African Walnut (Coulaedulis). Chem. Class J., 2005; 2:7476.

14. Ali F, Assanta MA \& Robert C. Gnetum africanum: A wild food plant from the African forest with many nutritional and medicinal purposes. Journal of Medicinal Foods, 2011; 14(11):1289 - 1297

15. Mailoundama, F. Nutritional and Socio-Economic Value in Central African Forest. In: Itladikom, et al., Eds., Tropical Forest People and Food: Bio-Cultural Interactions and Applications to Development, Parthenon Publishing Group, Carnforth. 1993

16. Okafor JC. Conservation and use of traditional vegetables from woody forest species in Southeastern Nigeria. In: Guarino L (Ed). Proceedings of the IPGRI international workshop on genetic resources of traditional vegetables in Africa: Conservation and use 1995 Conference. Kenya: ICRAF. 1997; Pp 31-38.

17. Iwu MM. Handbook of African Medicinal Plants, second ed. Taylor and Francis Group, Florida. 2010; Pp 224-226.

18. Eleazu CO, Eleazu KC. Health promoting compounds and in vitro antioxidant activity of raw and decoctions of GnetumaficanumWelw. Asian Pac J Trop Dis 2013; 3(6):472479.

19. Boxin OU, Dejian H, Maureen AF, Elizabeth KD. Analysis of antioxidant activities of common vegetables employing Oxygen Radical Absorbance Capacity (ORAC) and Ferric Reducing Antioxidant Power (FRAP) Assay: A comparative study. J. Agric. Food Chem. 2002; 5:223 - 338.

20. Senthil N, Manoharan S. Lipid peroxidation and antioxidants status in patients with papillary thyroid carcinoma in India. Asia Pac J ClinNutr; 2004; 13(4):391 - 395.

21. Ames BN, Shigenaga MK, Hagen TM. Oxidants, antioxidants, and the degenerative diseases of aging. Proceedings National Acad Sci. 1993 Sep 1; 90(17):7915-22.

22. Halliwell B. Free radicals, antioxidants, and human disease: curiosity, cause, or consequence? 1994; 344(8924):721 - 724.

23. Yadav, A., Kumari, R., Yadav, A., Mishra, J.P., Srivatva, S. and Prabha, S. Antioxidants and its functions in human body-A Review. Res. Environ. Life Sci., 2016; 9(11):1328-1331.

24. Hearther, K. V. and Talcott, S. Phytochemicals in plant-based foods could help battle obesity, disease. Journal of Human Nutrition and Dietetics, October, 2009. University of Florida. 2009.

25. Dembinska-Kiec, A., Mykkanen, O., Kiec-Wilk, B. and Mykkanene, H. Antioxidants phytochemicals against Type 2 diabetes. British J. Nutri, 2008; 99: 109-117.

26. Tijjani MA, Abduraham FI, Buba SW, Mala GI, Akan JC, Aji BM, Abdullahi AS. Chemical and Proximate Content or Methanolic leaf extract of Pilistigma thonningii schum Camel foot. J. Chem. Pharm. Res. 2012; 4(5):2409-2414.

27. Willis, L.M., Shukitt-Hale, B. and Joseph, J.A. Recent advances in berry supplementation and age-related cognitive decline. Current opinion in clinical nutrition and metabolic care, 2009; 12: 91-94.

28. Trease, G. E. and Evans, W. C. Pharmacognisy.11th edn.BrailliarTiridel Can. Macmillian publishers. 1989.

29. Mensor, LL, Fabio, SM, Gilda, GL, Alexandre, SR., Tereza, CD, Cintia, SC Suzana, GL. Screening of Brazilian plant extracts for antioxidant activity by the use of DPPH free radical method. Phytother. Res.; 2001; 15:127-130.

30. Oteng-Gang, K. and Mbachu, J.I. Changes in the Ascorbic Acid Content of Some Tropical Leafy Vegetables during Traditional Cooing and Local Processing. Journal of Food Chemistry, 1990; 23:9-17.

31. Owolabi OJ, Amaechina FC, Okoro M. Effect of ethanol leaf extract of Newbouldialaevis on blood glucose level of diabetic rats. Trop. J. Pharm. Res. 2011; 10(3):249-254.

32. Egba SI, Uzoegwu PN, Emmanuel TN, Joshua PE. Anti- sickling potential of the ethanol seed extract of Vignaunguiculata and Vigna subterranean. Int. J. Adv. Pharm. Nanotechnol. 2012; 2(3):178-181.

33. Kuzuyama T, Seto H. Diversity in the biosynthesis of Isoprene units. Nat. Prod. Rep. 2003; 20(2):171-183. 
34. Tijjani MA, Abduraham FI, Buba SW, Mala GI, Akan JC, Aji BM, Abdullahi AS. Chemical and Proximate Content or Methanolic leaf extract of Pilistigma thonningii schum Camel foot. J. Chem. Pharm. Res. 2012; 4(5):2409-2414

35. Mensah JK, Irenyen JO, Okhiure MO. Nutritional Phytochemical and Antimicrobial Properties of two wild Aromatic Vegetables from Edo State. J. Nat. Prod. Plants Res. 2013; 3(21):8-14.

36. Asquith TN, Butler LG. Interaction of condensed tannin with proteins. Phytochemistry 1986; 2(7):1591-1593.

37. Okwu DE. Evaluation of the chemical composition of indigenous spices and flavouriing agents. Global J. Pure Appl. Sci. 2001; 7:455-459.

38. Poli G, Cottalaso D, Prontazo M, Chairpotto E. Lipid peroxidation and covalent binding in the early functional impairment of liver Golgi Apparatus by CCl4. Cell Biochem. Funct. 1990; 8:1-10.

39. Sakihama, Y., Cohen, M. F., Grace, S. C. and Yamasaki, H. Plant phenolic antioxidant and prooxidant activities: phenolics- induced oxidative damage mediated by metals in plants Toxicology, 2002; 177:67-80.

40. Rice-Evans, C., Miller, N. and Paganga, G. Antioxidant properties of phenolic compounds. Trends Plant Sci. 1997; $2: 152-159$

41. Nwankpa P, Chukwuemeka OG, Ugwuezumba PC, Ekweogu CN, Etteh CC, Emengaha FC, Egwurugwu JN, Ngwu EE. Assessment of Anti-Oxidative Potential of Ethanol Seed Extract of Cola lepidota in High Fat Fed Female Wistar Albino Rats. East African Scholars J Med Sci; 2018; 1(2):47 - 53.

42. Esterbauer, H., Eckl, P., Ortner, A. Possible mutagens derived from lipids and lipid precursors. Mutagen Research; 1990; 238:223 - 233.

43. Oktay, M. Gulcin, I. and Kufrevioglu, O. I. Determination of in vitro antioxidant activity of Fennel (Foeniculumvulgare) seed extracts. Lebensm. Wiss Technol. 2003; 36:363-371.

44. Essien, E. E., Peter, N. S. and Akpan, S. M. Chemical Composition and Antioxidant Property of Two Species of Monkey Kola (Cola rostrata and Cola lepidota K. Schum) Extracts. Euro. J. Med. Plants, 2015; 7(1):31-37. 